\title{
SPATIALITY OF SOIL CHEMICAL ATTRIBUTES IN A BANANA CULTIVATION AREA IN WEST BAHIA ${ }^{1}$
}

\author{
BARBEMILE DE ARAÚJO DE OLIVEIRA ${ }^{2}$, LILIANE PEREIRA CAMPOS ${ }^{3}$, SAMMY SIDNEY ROCHA MATIAS $^{3 *}$, \\ TAMIRES SOARES DA SILVA ${ }^{4}$, ADRIANO VENICIÚS SANTANA GUALBERTO ${ }^{5}$
}

\begin{abstract}
Irrigated fruit growing in the São Francisco Valley has been standing out in the Northeast region of Brazil and the incorrect management of fertilization has caused problems of physical and / or chemical degradation of the soil. The work aimed to evaluate the spatial variability of the chemical attributes of a Latossolo Vermelho-Amarelo (Oxisol) grown with banana (Musa spp). The study was carried out in the irrigated perimeter of Nupeba in Riachão das Neves / BA. In an area cultivated for 18 years with silver banana fertigated by micro sprinkling. In April 2017 simple soil samples were collected at depths of $0-0.20 \mathrm{~m}$ and 0.20 $-0.40 \mathrm{~m}$, from an experimental grid consisting of 40 georeferenced points and spaced every 10 meters. The soil samples determined: $\mathrm{pH}\left(\mathrm{H}_{2} \mathrm{O}\right)$; Organic carbon; Phosphorus $(\mathrm{P})$; Potassium $\left(\mathrm{K}^{+}\right)$; Calcium $\left(\mathrm{Ca}^{2+}\right)$; Magnesium $\left(\mathrm{Mg}^{2+}\right)$ and Potential acidity $(\mathrm{H}+\mathrm{Al})$ and the sum of bases (BS), cation exchange capacity (CEC) and base saturation (V\%) were calculated. The results of the analyses were evaluated using descriptive statistics and the geostatistics technique. The descriptive analysis identified the normality of the data. The spatial variability was confirmed, allowing the making of maps. The analyzed area has low fertility $(\mathrm{V}<55 \%)$ and the inadequate management of soil correction and fertilization can reduce the availability of nutrients for the implanted crop, making the soil susceptible to degradation with the use of irrigation. The distribution maps allow the visualization of the area, allowing the application of inputs with varying rates, aiming at homogenizing the soil fertility.
\end{abstract}

Keywords: Musa spp. Distribution maps. Soil fertility.

\section{ESPACIALIDADE DOS ATRIBUTOS QUÍMICOS DO SOLO EM ÁREA DE CULTIVO DE BANANEIRA NO OESTE DA BAHIA}

\begin{abstract}
RESUMO - A fruticultura irrigada no Vale do São Francisco vem se destacando na região Nordeste do Brasil e o manejo incorreto da adubação tem proporcionado problemas de degradação física e/ou química do solo. $\mathrm{O}$ trabalho teve como objetivo avaliar a variabilidade espacial dos atributos químicos de um Latossolo VermelhoAmarelo cultivado com banana (Musa spp). O estudo foi realizado no perímetro irrigado de Nupeba em Riachão das Neves/BA. Em uma área cultivada por 18 anos com banana prata fertirrigada por microaspersão. Em abril de 2017 coletou-se amostras simples de solo nas profundidades de 0-0,20 m e de 0,20-0,40 m, a partir de uma malha experimental constituída de 40 pontos georreferenciados e distanciados a cada 10 metros. Nas amostras de solo foram determinados: $\mathrm{pH}\left(\mathrm{H}_{2} \mathrm{O}\right)$; Carbono orgânico; Fósforo (P); Potássio $\left(\mathrm{K}^{+}\right)$; Cálcio $\left(\mathrm{Ca}^{2+}\right)$; Magnésio $\left(\mathrm{Mg}^{2+}\right)$ e Acidez potencial $(\mathrm{H}+\mathrm{Al})$ e calculados a soma de bases $(\mathrm{SB})$, capacidade de troca catiônica (CTC) e saturação por bases (V\%). Os resultados das análises foram avaliados por meio da estatística descritiva e a técnica da geoestatistica. A análise descritiva identificou a normalidade dos dados. A variabilidade espacial foi confirmada, permitindo a confecção de mapas. A área analisada possui baixa fertilidade $(\mathrm{V}<55 \%)$ e $\mathrm{o}$ manejo inadequado de correção e adubação do solo podem reduzir a disponibilidade dos nutrientes para a cultura implantada, tornando o solo passível de degradação com o uso da irrigação. Os mapas de distribuição permitem a visualização da área, possibilitando a aplicação de insumos com taxa variada, visando à homogeneização da fertilidade do solo.
\end{abstract}

Palavras-chave: Musa spp. Mapas de distribuição. Fertilidade do solo.

\footnotetext{
"Corresponding author

${ }^{1}$ Received for publication in 02/17/2020; accepted in 10/26/2020

Paper extracted from the monography of the first author.

${ }^{2}$ JH Sementes LTDA, Correntina, BA, Brazil; barbemile.a@hotmail.com - ORCID: 0000-0001-6380-3490.

${ }^{3}$ Department of Agronomy, Universidade Estadual do Piaú, Corrente, PI, Brazil; lclilianecampos@gmail.com - ORCID: 0000-0001-85356257, ymmsa2001@yahoo.com.br - ORCID: 0000-0002-5729-3284.

${ }^{4}$ Department of Plant Production, Universidade Federal do Vale do São Francisco, Petrolina, PE, Brazil; tamyressoares.ts@gmail.com ORCID: 0000-0002-0494-1831.

${ }^{5}$ Department of Agricultural Sciences, Universidade Federal do Piaú, Bom Jesus, PI, Brazil; a.vsg@hotmail.com - ORCID: 0000-0002$1764-5564$.
} 


\section{INTRODUCTION}

Fruit production in Brazil has a volume of 40.5 million tons (GERUM et al., 2019), being considered the third world fruit producer, behind only China and India, this volume represents $5 \%$ of the world fruit crop production (FAO, 2016). The Northeastern region of Brazil is responsible for $27 \%$ of this production and the State of Bahia (13\%) is the second largest Brazilian producer, behind São Paulo (40\%) (GERUM et al., 2019).

Among the fruits cultivated in Brazil, banana (Musa spp.) is in second place in production volume being responsible for $16.7 \%$ of the national production, behind only citrus (orange, lemon and tangerine) that represent $48.2 \%$ of the national production. However, banana cultivation under tropical or semi-arid climate conditions requires supplementary irrigation to rains because evapotranspiration is higher than precipitation. Efficient irrigation management is crucial to obtain high yields in agricultural fruit production (FERREIRA et al., 2016; GERUM et al., 2019).

However, the areas submitted to the irrigated perimeters have presented problems of soil degradation (physical and chemical), resulting from inadequate soil management (DANTAS et al., 2012). Irrigation provides adequate water for plant growth, so that they can express their full genetic potential. However, irrigation generally results in excessive water application in some planting areas and insufficient water in others due to the non-uniformity of the cultivated areas, thus being able to directly influence the productivity of irrigated crops and increase the costs of agricultural projects (FERREIRA et al., 2016).

Studies by Lima et al. (2015) and Vian et al. (2016), showed that the determination of soil variability using technological tools such as geostatistics is essential for the correct soil-plantatmosphere interaction, as it allows different application of water according to the needs of each area (management specific), favoring yield optimization, increasing the efficiency of inputs, maximizing benefits and reducing costs.

According to Matias et al. (2015), soil variability information is essential to plan and implement more efficient, profitable and environmentally sustainable agriculture, with regard to the use of correctives and fertilizers, because it allows to apply in the right place and appropriate time the quantities necessary for agricultural production, making it essential to assist in the efficient management of soil and water.

The use of geostatistics can enhance the increase in Brazilian fruit production, due to the ability to determine specific management zones for effective correction of crop needs in the management of soil and water (MATIAS et al., 2019). However, to outline a specific management area, it is necessary to carry out joint analyses of the attributes that affect crop productivity (CÓRDOBA et al., 2013; YAO et al., 2014; HAGHVERDI et al., 2015), that vary vertically and horizontally across the landscape (SIQUEIRA et al., 2015).

Therefore, the present work aimed to evaluate the spatial variability of soil chemical attributes in a banana-cultivated area in the irrigated perimeter of Nupeba-Riacho Grande, western Bahia.

\section{MATERIALS AND METHODS}

The study was carried out in the Nupeba irrigated perimeter managed by the São Francisco and Parnaíba Valleys Development Company (CODEVASF, 2020) located in the municipality of Riachão das Neves / BA (11 44'49"S and $11^{\circ}$ 54'23" $\mathrm{O}, 440 \mathrm{~m}$ altitude), in the West of Bahia. The climate of the region, according to the current classification by Köppen cited by Alvares et al. (2013), is of the Aw type, hot and semi-humid. The average annual temperature is $27^{\circ} \mathrm{C}$, with an average annual rainfall of $1.000 \mathrm{~mm}$ and the rainy season is from October to April, with November, December and January being the rainiest months (INMET, 2020). The soil is classified as dystrophic Latossolo Vermelho-Amarelo (Oxisol), with a sandy-clay texture (SANTOS et al., 2018).

A 2 hectare Cerrado area was selected and cultivated with banana trees for 18 years, the cultivar is banana type Prata, with a spacing of $2.4 \mathrm{~m}$ between plants and between single and double rows, respectively, 2.0 and $4.0 \mathrm{~m}$, fertigated by micro sprinkling. In December/2015 the area received $2 \mathrm{t} \mathrm{ha}^{-1}$ of dolomitic limestone, in addition to the following fertilizations according to the crop production cycle: biweekly fertilizations with $55 \mathrm{~g}$ of potassium chloride and $30 \mathrm{~g}$ of ammonium sulfate; monthly fertilizations $120 \mathrm{~g}$ of simple superphosphate. The characterization of the chemical and physical attributes of the soil collected at a depth of $0-0.20 \mathrm{~m}$ in January 2017 and analyzed using the methodology proposed by Donagemma et al. (2011), before the implementation of fertigation are described in Table 1 and the characterization of fertigation which started in February 2017 is in Table 2 .

In April 2017, simple deformed soil samples were collected, from a regular grid of 40 georeferenced points and spaced every $10 \mathrm{~m}$, at depths of $0-0.20 \mathrm{~m}$ and $0.20-0.40 \mathrm{~m}$, totaling 80 samples, 40 per depth. The collected soil samples were air dried, ground, macerated and passed through a $2 \mathrm{~mm}$ mesh sieve (TFSA) and sent for laboratory analysis. 
B. A. OLIVEIRAet al.

Table 1. Result of the chemical and physical attributes of the soil at a depth of $0-0.20 \mathrm{~m}$, in an area cultivated with banana before the experiment (2017).

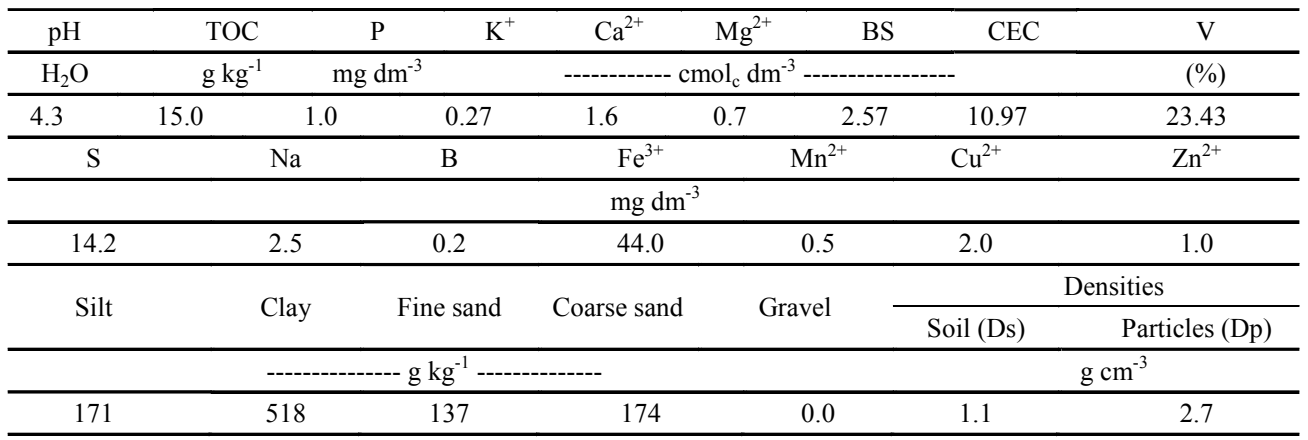

Source: Codevasf (2020).

Table 2. Data on fertigation of the banana plantation (Prata) in 2017.

\begin{tabular}{|c|c|c|c|c|c|c|c|}
\hline B & $\mathrm{Cu}^{2+}$ & $\mathrm{Mn}^{2+}$ & $\mathrm{Zn}^{2+}$ & Dilution & Conductivity & Fertigation time & Lead time \\
\hline \multicolumn{3}{|c|}{ 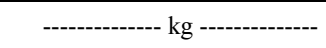 } & & & $\mathrm{dS} \mathrm{m}^{-1}$ & Min & Min \\
\hline 1.4 & 800 & 11.6 & 2.8 & $440 / 1$ & 0.96 & 32 & 18 \\
\hline
\end{tabular}

Source: Codevasf (2020).

They were analyzed, following the methodology of Donagemma et al. (2011): pH in $\mathrm{H}_{2} \mathrm{O}$; calcium $\left(\mathrm{Ca}^{2+}\right)$ and magnesium $\left(\mathrm{Mg}^{2+}\right)$ by extraction with potassium chloride $(\mathrm{KCl}) 1 \mathrm{~mol} \mathrm{~L}^{-1}$ and quantified in titulometry by EDTA complexometry; phosphorus (P) with Mehlich-1 extractor and colorimetric determination; potassium $\left(\mathrm{K}^{+}\right)$was extracted with diluted hydrochloric acid solution and determined by flame photometry; Total Organic Carbon (TOC) by hot oxidation using potassium dichromate; potential acidity $(\mathrm{H}+\mathrm{Al})$ by extraction with buffered calcium acetate solution at pH 7.0 quantified by titration with sodium hydroxide $(\mathrm{NaOH})$ and phenolphthalein as an indicator; aluminum $\left(\mathrm{Al}^{3+}\right)$ determined by extraction with $\mathrm{NaOH}$ in the presence of bromothymol blue as an indicator. The sum of bases (BS), cation exchange capacity (CEC) and base saturation (V) were calculated.

Statistical analysis was carried out by means of an exploratory study of the data using the
MINITAB ${ }^{\circledR}$ software, the measurement of location (mean, median, minimum and maximum), the measures of variability (coefficient of variation $\mathrm{CV} \%$ ) were calculated and the measures of central tendency (asymmetry and kurtosis), to verify the normality of the chemical attributes evaluated.

Semivariograms were obtained using the $\mathrm{GS}^{+\circledast}$ program (ROBERTSON, 2008) and the following models were adjusted to the data: (a) spherical, (b) exponential, (c) Gaussian. From these models, attributes were predicted in areas not sampled by kriging, represented on contour maps, using the SURFER ${ }^{\circledR}$ program. The degree of spatial dependence (GDE) was classified based on the nugget effect and sill $\left(\mathrm{C}_{0} / \mathrm{C}_{0}+\mathrm{C}_{1}\right)$, being considered weak above $75 \%$, moderate between $25 \%$ and $75 \%$ and strong below 25\% (CAMBARDELLA et al., 1994). In the maps of the spatial distribution of soil chemical attributes, the contents were interpreted according to the description made by Ribeiro, Guimarães and Alvarez (1999), described in Table 3.

Table 3. Interpretation of the results of water $\mathrm{pH}$ analysis, phosphorus, potassium, calcium, magnesium, aluminum, hydrogen + aluminum, sum of bases, cation exchange capacity and base saturation.

\begin{tabular}{|c|c|c|c|c|c|}
\hline \multirow{3}{*}{$\mathrm{pH}$ in $\mathrm{H}_{2} \mathrm{O}$} & Very high acidity & High acidity & Medium & Weak & Alkaline \\
\hline & $<4.5$ & $4.5-5.0$ & $5.1-6.0$ & $6.1-6.9$ & $>7.0$ \\
\hline & Very low & Low & Medium & Good & Very good \\
\hline $\mathrm{K}^{+} \mathrm{cmol}_{\mathrm{c}} \mathrm{dm}^{-3}$ & $<0.50$ & $0.5-1.0$ & $1.0-2.0$ & ----- & $>2.00$ \\
\hline $\mathrm{P} \mathrm{mg} \mathrm{dm}{ }^{-3}$ & $<8.0$ & $8.1-11.4$ & $11.5-15.8$ & $15.9-24.00$ & $>24.00$ \\
\hline $\mathrm{Ca}^{2+} \mathrm{cmol}_{\mathrm{c}} \mathrm{dm}^{-3}$ & 0.40 & $0.41-1.20$ & $1.21-2.40$ & $2.41-4.00$ & $>4.00$ \\
\hline $\mathrm{Mg}^{2+} \mathrm{cmol}_{\mathrm{c}} \mathrm{dm}^{-3}$ & 0.15 & $0.16-0.45$ & $0.46-0.90$ & $0.91-1.50$ & $>1.50$ \\
\hline $\mathrm{H}+\mathrm{Al} \mathrm{cmol}_{\mathrm{c}} \mathrm{dm}^{-3}$ & 1.00 & $1.01-2.50$ & $2.51-5.00$ & $5.01-9.00$ & $>9.00$ \\
\hline BS $\mathrm{cmol}_{\mathrm{c}} \mathrm{dm}^{-3}$ & 0.60 & $0.61-1.80$ & $1.81-3.60$ & $3.61-6.00$ & $>6.00$ \\
\hline $\mathrm{CEC} \mathrm{cmol}_{\mathrm{c}} \mathrm{dm}^{-3}$ & 1.60 & $1.61-4.30$ & $4.31-8.60$ & $8.61-15.00$ & $>15.00$ \\
\hline $\mathrm{V} \%$ & 20.0 & $20.1-40.0$ & $40.1-60.0$ & - & - \\
\hline
\end{tabular}

Source: Ribeiro, Guimarães and Alvarez (1999).

Rev. Caatinga, Mossoró, v. 34, n. 1, p. 177 - 188, jan. - mar., 2021 


\section{RESULTS AND DISCUSSION}

There is an approximation of the mean and median values for each variable, demonstrating a normal distribution of data at each depth (Table 4).

According to Negreiros Neto et al. (2014), the data present or approximate the normal distribution when the mean, median values consist of similar values. Additionally, the values of asymmetry and kurtosis show values close to zero, confirming the normal distribution in the depths analyzed and, thus, the use of Geostatistics for this assessment is applicable (LIMA et al., 2015; FERREIRA et al., 2016; MATIAS et al., 2019).

Regarding the coefficient of variation (CV\%), the values presented heterogeneous series, that is, with high variability in attributes except for $\mathrm{pH}$, potential acidity $(\mathrm{H}+\mathrm{Al})$, sum of bases $(\mathrm{BS})$, cation exchange capacity (CEC) and base saturation (V\%). To Bottega et al. (2013), the variability of chemical attributes is a representation of the interaction of formation processes and management practices carried out in the soil, such as the application of correctives and fertilizers and probably, due to this, the $\mathrm{CV} \%$ values for these variables were greater than $35 \%$.

The asymmetry coefficient is used to characterize how and how much the frequency distribution deviates from the symmetry. If the value found for this coefficient is zero, the distribution is symmetric, when it is positive, the distribution is asymmetric on the right; and if negative, it is asymmetric on the left (WERNER et al., 2012). Thus, the attribute $\mathrm{H}+\mathrm{Al}$ showed an asymmetry on the left at both depths $(-0.01 ;-0.22)$ and most attributes showed an asymmetric distribution on the right, between the values 0.12 and 1.68 (Table 4). This result, in general, demonstrates that the frequency and distribution is of the normal type, in agreement with those observed by other authors (DANTAS et al., 2012; LIMA et al., 2015; CARNEIRO et al., 2016; MATIAS et al ., 2019) who studied spatial variability through soil attributes.

Table 4. Descriptive statistics of soil chemical attributes at depths of $0-0.20 \mathrm{~m}$ and $0.20-0.40 \mathrm{~m}$.

\begin{tabular}{|c|c|c|c|c|c|c|c|c|c|}
\hline \multirow{2}{*}{ Attribute } & \multirow{2}{*}{ Depth (m) } & \multirow{2}{*}{ Méd } & \multirow{2}{*}{ Med } & \multirow{2}{*}{ DP } & \multirow{2}{*}{ Min. } & \multirow{2}{*}{ MAx } & \multicolumn{3}{|c|}{ Coefficients } \\
\hline & & & & & & & Ass & Curt & $\mathrm{CV}(\%)$ \\
\hline \multirow{2}{*}{$\begin{array}{c}\mathrm{pH} \\
\mathrm{H}_{2} \mathrm{O}\end{array}$} & $0-0.20$ & 5.01 & 4.92 & 0.42 & 4.09 & 6.00 & 0.19 & -0.58 & 8.53 \\
\hline & $0.20-0.40$ & 4.55 & 4.53 & 0.24 & 3.98 & 5.05 & -0.36 & 0.33 & 5.30 \\
\hline \multirow{2}{*}{$\begin{array}{l}\text { TOC } \\
\mathrm{g} \mathrm{kg}^{-1}\end{array}$} & $0-0.20$ & 0.98 & 1.03 & 0.37 & 0.12 & 1.58 & -0.53 & -0.45 & 38.21 \\
\hline & $0.20-0.40$ & 0.80 & 0.82 & 0.25 & 0.34 & 1.40 & 0.27 & -0.04 & 31.73 \\
\hline \multirow{2}{*}{$\begin{array}{c}\mathrm{P} \\
\mathrm{mg} \mathrm{dm}\end{array}$} & $0-0.20$ & 53.86 & 52.22 & 23.21 & 16.98 & 185.21 & 0.77 & 0.65 & 43.09 \\
\hline & $0.20-0.40$ & 13.57 & 16.75 & 5.78 & 2.74 & 19.37 & -1.00 & -0.77 & 42.64 \\
\hline \multirow{2}{*}{$\begin{array}{c}\mathrm{K}^{+} \\
\mathrm{cmol}_{\mathrm{c}} \mathrm{dm}^{-3}\end{array}$} & $0-0.20$ & 0.25 & 0.21 & 0.12 & 0.07 & 0.56 & 0.67 & -0.20 & 50.43 \\
\hline & $0.20-0.40$ & 0.19 & 0.18 & 0.09 & 0.06 & 0.44 & 0.73 & 0.05 & 48.72 \\
\hline \multirow{2}{*}{$\begin{array}{c}\mathrm{Ca}^{2+} \\
\mathrm{cmol}_{\mathrm{c}} \mathrm{dm}^{-3}\end{array}$} & $0-0.20$ & 3.20 & 3.20 & 1.35 & 1.18 & 5.80 & 0.39 & -1.01 & 42.17 \\
\hline & $0.20-0.40$ & 1.21 & 1.10 & 0.70 & 0.50 & 3.50 & 1.68 & 3.29 & 57.56 \\
\hline \multirow{2}{*}{$\begin{array}{c}\mathrm{Mg}^{2+} \\
\mathrm{cmol}_{\mathrm{c}} \mathrm{dm}^{-3}\end{array}$} & $0-0.20$ & 2.78 & 2.50 & 0.95 & 0.40 & 5.10 & 0.50 & 0.69 & 34.44 \\
\hline & $0.20-0.40$ & 0.72 & 0.50 & 0.45 & 0.00 & 1.90 & 0.75 & -0.09 & 62.25 \\
\hline \multirow{2}{*}{$\begin{array}{c}\mathrm{H}+\mathrm{Al} \\
\mathrm{cmol}_{\mathrm{c}} \mathrm{dm}^{-3}\end{array}$} & $0-0.20$ & 7.36 & 7.50 & 1.85 & 4.29 & 10.56 & -0.01 & -1.25 & 25.13 \\
\hline & $0.20-0.40$ & 7.22 & 7.17 & 1.38 & 3.79 & 9.57 & -0.22 & -0.24 & 19.22 \\
\hline \multirow{2}{*}{$\begin{array}{c}\text { BS } \\
\mathrm{cmol}_{\mathrm{c}} \mathrm{dm}^{-3}\end{array}$} & $0-0.20$ & 6.18 & 6.35 & 1.75 & 2.34 & 10.38 & 0.12 & -0.38 & 28.31 \\
\hline & $0.20-0.40$ & 2.03 & 1.97 & 0.72 & 1.06 & 4.15 & 1.23 & 1.73 & 11.65 \\
\hline \multirow{2}{*}{$\begin{array}{c}\mathrm{CEC} \\
\mathrm{cmol}_{\mathrm{c}} \mathrm{dm}^{-3}\end{array}$} & $0-0.20$ & 15.50 & 16.00 & 4.48 & 4.74 & 25.26 & -0.05 & -0.38 & 28.90 \\
\hline & $0.20-0.40$ & 4.77 & 4.53 & 1.85 & 2.25 & 9.55 & 0.92 & 0.51 & 38.78 \\
\hline \multirow{2}{*}{ V\% } & $0-0.20$ & 39.75 & 39.55 & 0.93 & 38.20 & 41.69 & 0.39 & -0.95 & 2.33 \\
\hline & $0.20-0.40$ & 42.39 & 42.05 & 2.68 & 39.09 & 49.70 & 1.17 & 1.16 & 6.32 \\
\hline
\end{tabular}

$\mathrm{CV}$ : Coefficient of Variation [CV\% = (Standard deviation / mean $) \times 100]$; BS: Sum of Bases $(\mathrm{BS}=\mathrm{Ca}+$ $\mathrm{Mg}+\mathrm{K})$; CEC: Cation Exchange Capacity $(\mathrm{CEC}=\mathrm{BS}+\mathrm{H}+\mathrm{Al})$; $\mathrm{V} \%$ : Base Saturation $[\mathrm{V} \%=(\mathrm{BS} /$ CEC) $\mathrm{x}$ 100], Méd $=$ mean, Med: median, Max $=$ maximum values, Min $=$ minimum values, $\mathrm{DP}=$ Standard deviation, Ass: Asymmetry; Curt: kurtosis.

Kurtosis coefficients are used to assess whether the data adopt a normal distribution. According to Negreiros Neto et al. (2014), kurtosis should preferably be null, but values between +2 and -2 can be accepted. It was observed that the kurtosis values were within the limits considered acceptable as mentioned above, except for the $\mathrm{Ca}$ analyzed at a depth of 0.20-0.40 m (3.29). Possibly the irregular replacement of dolomitic limestone in the area may have influenced this result (Table 4). 
The adjustment parameters of the semivariograms identified the spatial dependence (Table 5). The Gaussian and spherical models were the best adjusted, with the exception of BS in the first depth $(0-0.20 \mathrm{~m})$ and $\mathrm{V} \%$ in the second depth $(0.20-0.40 \mathrm{~m})$, which adjusted to the exponential model.

Table 5. Estimated models and parameters of semivariograms adjusted for soil chemical attributes at depths of $0-0.20 \mathrm{~m}$ and $0.20-0.40 \mathrm{~m}$.

\begin{tabular}{|c|c|c|c|c|c|c|c|}
\hline \multirow{2}{*}{ Attribute } & \multirow{2}{*}{ Depth (m) } & \multirow{2}{*}{ Model } & \multirow{2}{*}{ GDE (\%) } & \multirow{2}{*}{ Reach (m) } & \multirow{2}{*}{$\mathrm{R}^{2}$} & \multicolumn{2}{|c|}{ CVRC } \\
\hline & & & & & & $\mathrm{b}$ & A \\
\hline \multirow{2}{*}{$\begin{array}{c}\mathrm{pH} \\
\mathrm{H}_{2} \mathrm{O}\end{array}$} & $0-0.20$ & gaussian & 0.05 & 25.80 & 0.738 & 0.939 & 0.32 \\
\hline & $0.20-0.40$ & gaussian & 0.09 & 18.18 & 0.255 & 0.434 & 2.61 \\
\hline \multirow{2}{*}{$\begin{array}{l}\mathrm{TOC} \\
\mathrm{g} \mathrm{kg}^{-1}\end{array}$} & $0-0.20$ & gaussian & 38.54 & 31.17 & 0.794 & 0.858 & 0.14 \\
\hline & $0.20-0.40$ & gaussian & 14.81 & 32.77 & 0.818 & 1.00 & 0.00 \\
\hline \multirow{2}{*}{$\begin{array}{c}\mathrm{P} \\
\mathrm{mg} \mathrm{dm}\end{array}$} & $0-0.20$ & gaussian & 0.05 & 27.36 & 0.621 & 0.688 & 19.37 \\
\hline & $0.20-0.40$ & gaussian & 0.24 & 38.45 & 0.968 & 0.897 & 1.17 \\
\hline \multirow{2}{*}{$\underset{\mathrm{cmol}_{\mathrm{c}} \mathrm{dm}^{-3}}{\mathrm{~K}}$} & $0-0.20$ & spherical & 23.20 & 70.40 & 0.916 & 0.965 & 0.01 \\
\hline & $0.20-0.40$ & spherical & 0.07 & 58.80 & 0.724 & 0.991 & 0.00 \\
\hline \multirow{2}{*}{$\begin{array}{c}\mathrm{Ca} \\
\mathrm{cmol}_{\mathrm{c}} \mathrm{dm}^{-3}\end{array}$} & $0-0.20$ & gaussian & 0.04 & 27.19 & 0.848 & 0.967 & 0.16 \\
\hline & $0.20-0.40$ & spherical & 0.08 & 43.30 & 0.793 & 1.00 & -0.01 \\
\hline \multirow{2}{*}{$\underset{\text { cmol }_{\mathrm{c}} \mathrm{dm}^{-3}}{\mathrm{Mg}}$} & $0-0.20$ & spherical & 7.88 & 57.80 & 0.855 & 0.650 & 1.01 \\
\hline & $0.20-0.40$ & gaussian & 0.22 & 23.20 & 0.533 & 0.048 & 0.80 \\
\hline \multirow{2}{*}{$\begin{array}{c}\mathrm{H}+\mathrm{Al} \\
\mathrm{cmol}_{\mathrm{c}} \mathrm{dm}^{-3}\end{array}$} & $0-0.20$ & gaussian & 30.52 & 94.05 & 0.849 & 0.941 & 0.43 \\
\hline & $0.20-0.40$ & spherical & 16.35 & 95.90 & 0.814 & 0.732 & 1.93 \\
\hline \multirow{2}{*}{$\begin{array}{c}\text { BS } \\
\text { cmol }_{c} \mathrm{dm}^{-3}\end{array}$} & $0-0.20$ & exponential & 0.03 & 70.80 & 0.824 & 0.860 & 0.90 \\
\hline & $0.20-0.40$ & gaussian & 46.57 & 45.55 & 0.772 & 0.822 & 0.39 \\
\hline \multirow{2}{*}{$\begin{array}{c}\text { CEC } \\
\mathrm{cmol}_{\mathrm{c}} \mathrm{dm}^{-3}\end{array}$} & $0-0.20$ & gaussian & 0.04 & 27.71 & 0.723 & 0.959 & 0.88 \\
\hline & $0.20-0.40$ & spherical & 7.02 & 45.40 & 0.647 & 0.584 & 2.34 \\
\hline \multirow{2}{*}{$\mathrm{V} \%$} & $0-0.20$ & spherical & 6.87 & 17.33 & 0.720 & 0.619 & 15.21 \\
\hline & $0.20-0.40$ & exponential & 19.63 & 76.89 & 0.450 & 0.497 & 21.38 \\
\hline
\end{tabular}

GDE: Degree of spatial dependence $\left[\mathrm{GDE} \%=\left(\mathrm{C}_{0} / \mathrm{C}_{0}+\mathrm{C}_{1}\right) \times 100\right] ; \mathrm{R}^{2}$ : Coefficient of determination of the model; CVRC: Cross-Validation Regression coefficient; b: Angular coefficient; a: Interceptor; BS: Sum of Bases $(\mathrm{BS}=\mathrm{Ca}+\mathrm{Mg}+\mathrm{K})$; $\mathrm{CEC}$ : Cation exchange Capacity $(\mathrm{CEC}=\mathrm{BS}+\mathrm{H}+\mathrm{Al})$; $\mathrm{BS}$ : Base Saturation $[\mathrm{V} \%=(\mathrm{BS} / \mathrm{CEC}) \times 100]$.

Regarding the degree of spatial dependence (GDE\%), obtained by analyzing the $\mathrm{C}_{0} /\left(\mathrm{C}_{0}+\mathrm{C}_{1}\right) \mathrm{x}$ 100 ratio, it showed strong dependence for all attributes, with the exception of TOC (38.54\%) and $\mathrm{H}+\mathrm{Al}(30.52 \%)$, both in the first depth and BS (46.57\%) in the second depth (Table 5), all classified as moderate. Therefore, the distributions of chemical attributes in space are not random, since all presented moderate or strong values for the degree of spatial dependence. The strong spatial dependence obtained in the attributes is intensely influenced by intrinsic soil properties, such as texture and mineralogy (CAMBARDELLA et al., 1994; MATIAS et al., 2015; SIQUEIRA et al., 2015).

The range between the evaluated attributes has values between: $\mathrm{pH}(18.18 \mathrm{~m})$ and $\mathrm{H}+\mathrm{Al}(95.90$ $\mathrm{m})$, which correspond to the areas considered homogeneous. The reach values are influenced by agronomic practices (correction, fertilization, crop treatment, irrigation and harvesting), as it aims to homogenize the cultivation area (CARNEIRO et al., 2016, FERREIRA et al., 2016; MATIAS et al., 2019). It is a parameter that must be analyzed for ensuring that all points within a circle, with the demonstrated radius, are so similar that they can be used to estimate values for any point between them, with reliability (MATIAS et al., 2015; SIQUEIRA et al., 2015).

The highest values of the coefficient of determination of the model adjusted to the semivariogram $\left(\mathrm{R}^{2}\right)$ for the depth $0-0.20 \mathrm{~m}$ were observed in the exchangeable bases, $\mathrm{K}(91.6 \%)$, Ca $(84.8 \%)$ and $\mathrm{Mg}(85.5 \%)$ and in the potential acidity $(84.9 \%)$ of the soil. In subsurface $(0.20-0.40 \mathrm{~m})$, the highest values of $\mathrm{R}^{2}$ were observed for $\mathrm{P}(96.8 \%$, TOC $(81.8 \%)$ and $\mathrm{H}+\mathrm{Al}(81.4 \%)$ respectively. The $\mathrm{R}^{2}$ shows in percentage how much of the variation of the estimated values of semi-variance is explained by models, denoting that the semivariogram model meets the requirements of spatial interpolation. Similar results were reported by Paris et al. (2020), who evaluated soil attributes and macadamia productivity in Latosol areas and found a high degree of dependent variable by independent variables and by Vian et al. (2016), analyzing the production of maize. 
The cross-validation regression coefficient (CVRC) ranged from 61.9 to $96.7 \%$ for $\mathrm{V} \%$ and $\mathrm{Ca}$ at the surface depth $(0-0.20 \mathrm{~m})$ respectively, obtaining the lowest value for $\mathrm{Mg}(4.8 \%)$ and the highest values for $\mathrm{Ca}$ and TOC $(100 \%)$ at a depth of $0.20-0.40 \mathrm{~m}$. Cross-validation is the method that predicts the uncertainty of data prediction, that is, it verifies the reliability of the variogram model, which will reflect on the interpolation of the data and, consequently, in the mapping by kriging (MATIAS et al., 2015; SIQUEIRA et al., 2015). Lundgren, Silva and Ferreira (2017) evaluated several criteria and concluded that cross-validation is the appropriate method for selecting the best fit, showing that the highest CVRC values for estimating soil attributes, using kriging, present a lower error and, therefore, it is more reliable.

Based on the semivariograms, maps of the spatial distribution of the chemical attributes $\mathrm{pH}$, TOC, $\mathrm{P}, \mathrm{K}^{+}, \mathrm{Ca}^{2+}, \mathrm{Mg}^{2+}, \mathrm{H}+\mathrm{Al}$ were made at depths of $0-0.20 \mathrm{~m}$ and $0.20-0.40 \mathrm{~m}$ (Figure 1). According to Vian et al. (2016) and Matias et al. (2019), the construction of kriging maps allows the identification and demarcation of areas with greater and lesser variability in relation to soil attributes, aiming at the practice of the application of inputs with adequate quantities, for example, thus respecting the need of the plant. The delimitation of the areas through specific management (maps) using soil attributes enables nutrient introduction in the correct place and quantity, thereby avoiding excess and lack in certain areas (CÓRDOBA et al., 2013; YAO et al., 2014; HAGHVERDI et al., 2015).All variables analyzed showed variability, with the highest values in the soil surface depth of $0-0.20 \mathrm{~m}$ (Figure 1). It was observed that the $\mathrm{pH}$ had variations between very high acidity $(<4.5)$ and average acidity (5.1-6.0), with the banana growing better in soils with $\mathrm{pH}$ between 5.5 and 6.5 (RIBEIRO; GUIMARÃES; ALVAREZ, 1999; GERUM et al., 2019). Higher $\mathrm{pH}$ values at the surface $(0-0.20 \mathrm{~m})$ than at the depth $(0.20-0.40 \mathrm{~m})$ were also verified by Pereira et al. (2019) working in an irrigated perimeter area, stating that this acidity was probably due to fertigation, in addition to the clayey texture of the soil that makes corrective leaching difficult and the dolomitic limestone applied in the area without considering soil spatiality.

The TOC contents (between $0.1 \mathrm{~g} \mathrm{~kg}^{-1}$ and $1.4 \mathrm{~g} \mathrm{~kg}^{-1}$ ) remained similar between the depths because they were associated with the constant replacement of labile organic material, which may have favored the increase in the variability of the carbon stock at a depth of 0.20-0.40 m (Figure 1). Despite the incorporation of organic residues from the banana crop itself at each cycle, the TOC contents for both depths were low, suggesting that carbon was in the process of cycling. It has been reported that there is accelerated decomposition of organic material from banana (BORGES; SOUZA, 2010).

At a depth of $0-0.20 \mathrm{~m}$, it was observed that the $\mathrm{P}$ levels varied between 16.98 and $185.21 \mathrm{mg} \mathrm{dm}^{-3}$ (Figure 1). This result must be associated with constant monthly mineral fertilizations of simple superphosphate, according to the needs of the crop. At a depth of $0.20-0.40 \mathrm{~m}$ it presented levels between very low and good (2.74 to $\left.19.37 \mathrm{mg} \mathrm{dm}^{-3}\right)$, that is, it presented less variability within the depth because it is an element with little mobility in the soil (Figure 1). Emphasizing that phosphorus $(\mathrm{P})$ is one of the nutrients most required by banana crop, according to the recommendations of Borges and Souza (2010) the P contents found in the banana area $<30 \mathrm{mg} \mathrm{dm}^{-3}$, indicate that the whole area needs phosphate fertilization.

The results showed lower spatial variability of $\mathrm{K}^{+}$among the depths analyzed (Figure 1), presenting similar values ranging from 0.06 to $0.56 \mathrm{cmolc} \mathrm{dm}^{-3}$, classified as very low and low levels. Due to the fortnightly mineral fertilizations to be launched with potassium chloride and ammonia sulfate, according to the need of the crop; it is emphasized that banana requires high concentrations of $\mathrm{K}^{+}$and, in soils with $<0.60 \mathrm{cmol}_{\mathrm{c}} \mathrm{dm}^{-3}$, potassium fertilization is required to meet the crop demand (GERUM et al, 2019; ALVES et al., 2019). It was observed that the depth of $0.20-0.40 \mathrm{~m}$ presented a reduction which can be attributed to export by the fruits, agreeing with Alves et al. (2019), where they concluded that, in an area cultivated with banana trees under irrigation with wastewater, the reduction of $\mathrm{K}^{+}$in the soil can be justified by the greater extraction of the crop due to increased productivity.

The $\mathrm{Ca}$ in the analyzed area presented low and very good contents $\left(0.5\right.$ to $\left.5.8 \mathrm{cmol}_{\mathrm{c}} \mathrm{dm}^{-3}\right)$ (Figure 1) from the application of correctives at the $0-0.20 \mathrm{~m}$ depth of the soil, and the management was complemented by the deposition of crop residues that favored the uniformity and cycling of $\mathrm{Ca}^{2+}$. According to Carneiro et al. (2016), 94.5\% of the $\mathrm{Ca}^{2+}$ absorbed by the banana tree returns to the soil, through the deposition of plant residues. It should be noted that $\mathrm{Ca}^{2+}$ is an element of low mobility within the plant and must be distributed homogeneously in the soil, as its deficiency in the soil solution in the meristemic regions of the roots can indicate serious restrictions to root development (CARNEIRO et al., 2016). 

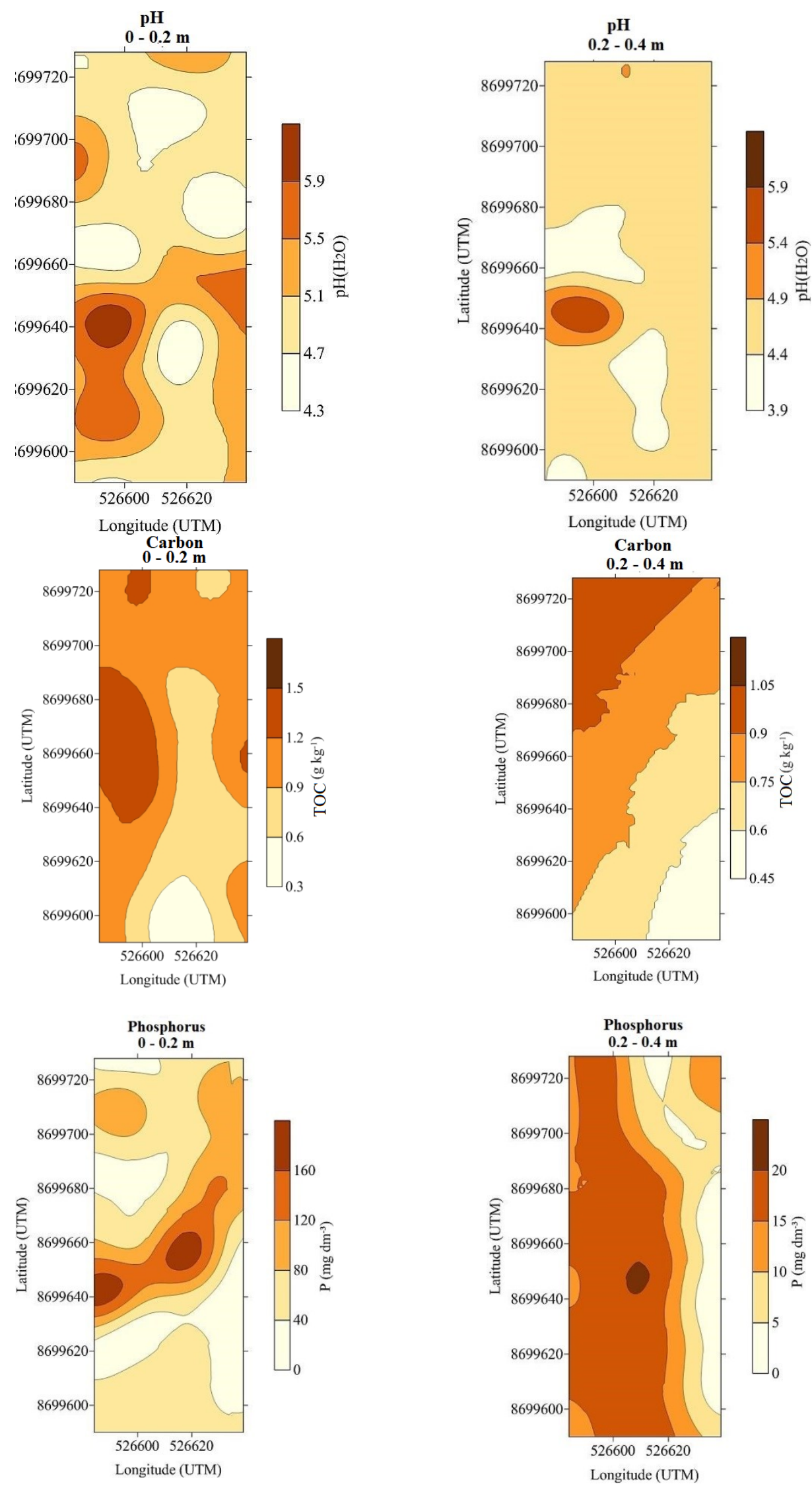

Figure 1. Maps of the spatial distribution of chemical attributes, $\mathrm{pH}, \mathrm{TOC}, \mathrm{P}, \mathrm{K}^{+}, \mathrm{Ca}^{2+}, \mathrm{Mg}^{2+}, \mathrm{H}+\mathrm{Al}$ at depths of $0-0.20 \mathrm{~m}$ and $0.20-0.40 \mathrm{~m}$, in the irrigated banana crop area implanted 18 years ago. 

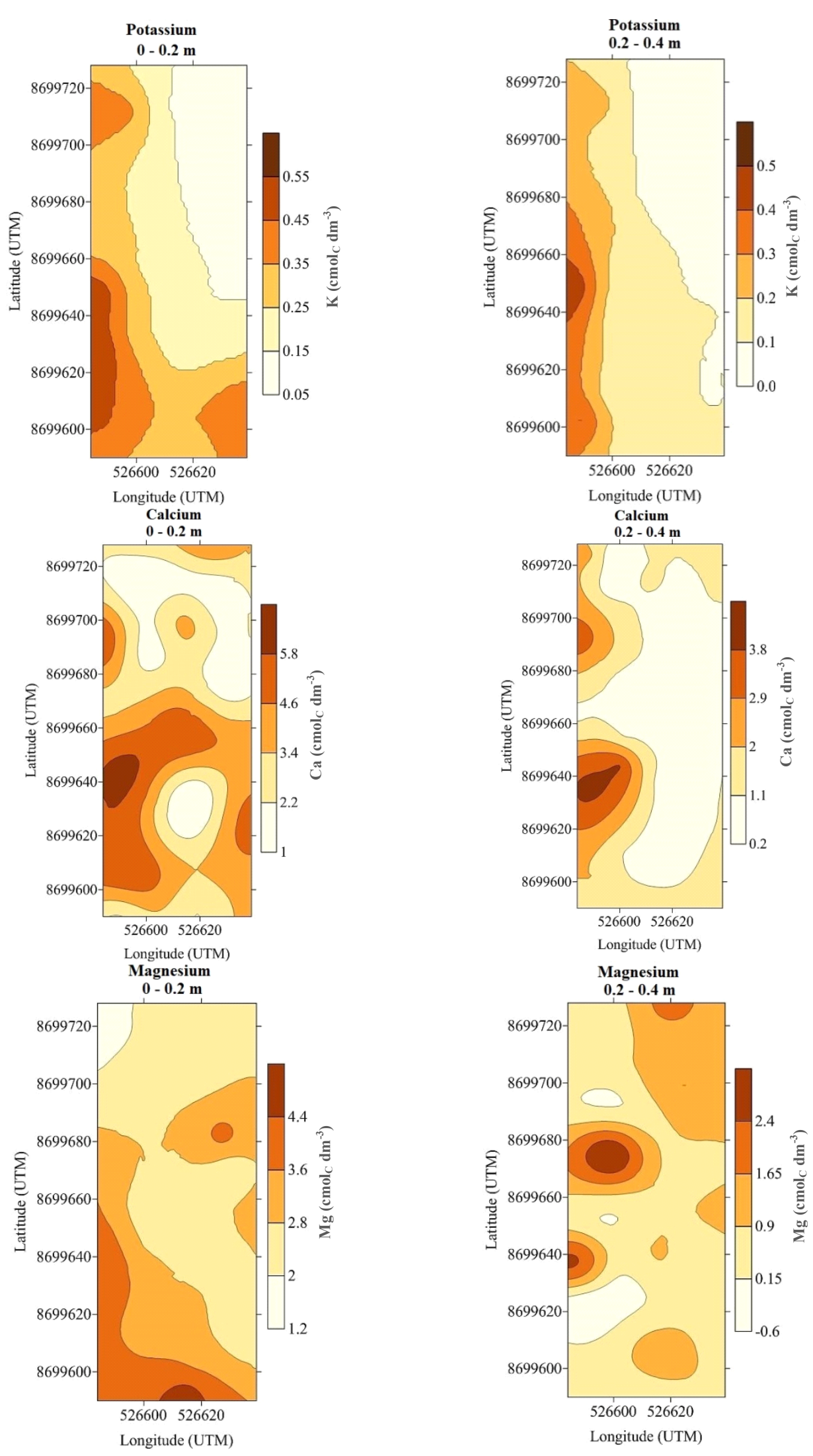

Figure 1. Continuation. 


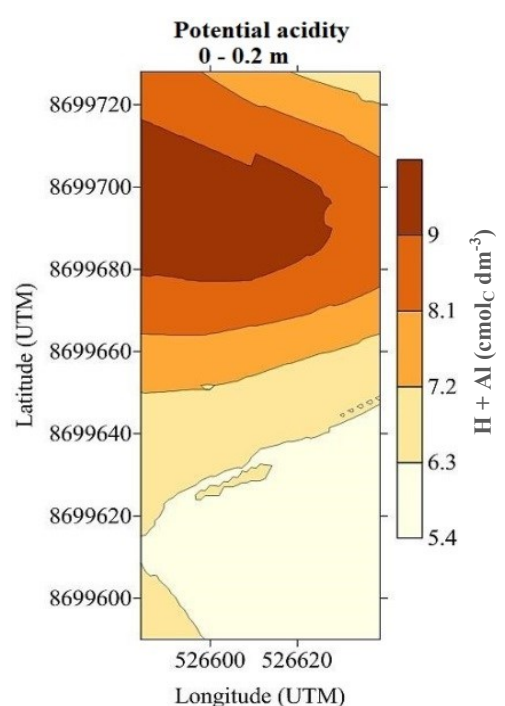

Figure 1. Continuation.

$\mathrm{Mg}$ contents vary between very low and very good $\left(0.0\right.$ to $\left.5.1 \mathrm{cmol}_{\mathrm{c}} \mathrm{dm}^{-3}\right)$ (Figure 1$)$, because, due to the $\mathrm{Ca} / \mathrm{Mg}$ ratio, the application of corrective agents, such as dolomitic limestone in the superficial depth, may have contributed to this result, together with the deposition of banana crop residues that favored the uniformity and cycling of $\mathrm{Mg}^{2+}$ and $\mathrm{Ca}^{2+}$. There was a decrease in levels at the $0.20-0.40 \mathrm{~m}$ depth, and this may be associated with greater absorption of this nutrient by banana crop, evidencing that there is a need for mg-based fertilization, as observed by Leite et al. (2013) in another irrigated perimeter.

Regarding the levels of $\mathrm{H}+\mathrm{Al}$, the values varied between medium and very good (3.79 to $10.56 \mathrm{cmol}_{\mathrm{c}} \mathrm{dm}^{-3}$ ) (Figure 1), in which, according to Leite et al. (2013), values above the average classification (Table 3), indicate that the cultivated area does not present toxicity problems, this implies that it does not hinder the development of roots and the availability of nutrients in the soil-plant relationship. It is worth mentioning that the higher the potential acidity, the greater the buffer power of the soil (the resistance of the soil to varying the $\mathrm{pH}$ when treated with acid or base), which may be associated with the content of organic matter or type of clay. On the other hand, in a soil with greater buffering power, it is necessary that a greater amount of limestone is added, so that there is a small change in $\mathrm{pH}$, it may be due to this, that the $\mathrm{pH}$ values in the two depths suffer little elevation.

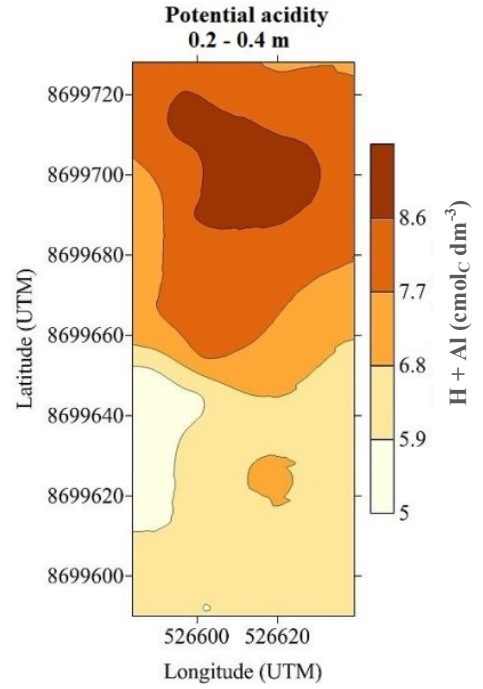

The values of sum of bases (BS), cation exchange capacity (CEC) and base saturation (V\%) of the evaluated area showed variability at depths of $0-0.20 \mathrm{~m}$ and $0.20-0.40 \mathrm{~m}$ (Figure 2). These variables analyzed, allow a new classification of soil fertility, because it is the sum and the participatory percentage of the bases in relation to the exchange of soil cations.

The depth BS presented levels classified as low to very good (1.06 to $10.38 \mathrm{cmol}_{\mathrm{c}} \mathrm{dm}^{-3}$ ) (Figure $2)$. In the superficial depth it can be associated with fertilization, however at depths of $0.20-0.40 \mathrm{~m}$, the values are smaller and present great variability in the whole area, resulting from the non incorporation of the dolomitic limestone (rich in bases like $\mathrm{Ca}$ and $\mathrm{Mg}$ ) in depth and the possible extraction of $\mathrm{K}$ by the crop or loss by leaching, due to its mobility in the soil.

The CEC showed higher values at a depth of $0-0.20 \mathrm{~m}$ (Figure 2), values that are classified as low and very good, respectively $(2.25$ to 25.26 $\mathrm{cmol}_{\mathrm{c}} \mathrm{dm}^{-3}$ ). The higher CEC values on the surface may be related to the higher content of organic matter from the deposition of labile material from the crop itself, in Cerrado soils, this accumulation generates negative charges (LEITE et al., 2013). The authors emphasized that it is important to analyze the CEC values with respect to fertility, as it indicates the capacity that the soil has to adsorb cations in exchangeable form, where in general, they will serve as nutrients to plants. 

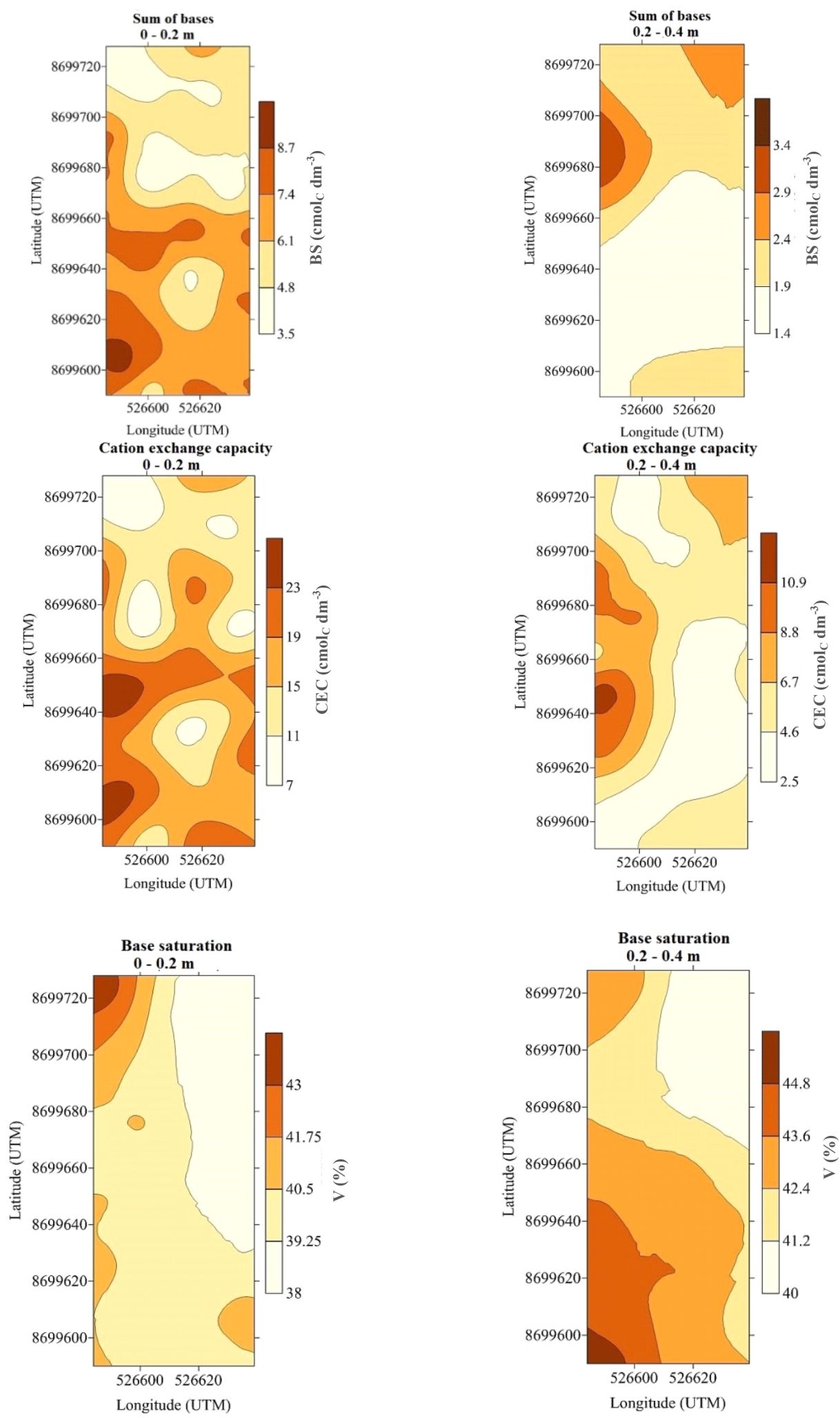

Figure 2. Maps of the spatial distribution of BS, CEC and V\% at depths of $0-0.20 \mathrm{~m}$ and $0.20-0.40 \mathrm{~m}$, in the area with irrigated banana cultivation implanted 18 years ago.

Base saturation ( $\mathrm{V} \%$ ) showed similar values between $0-0.20$ and $0.20-0.40 \mathrm{~m}$ depths (Figure 2), with average content classification $(40.1-60.0 \%)$ according to Ribeiro, Guimarães and Alvarez (1999), whose upper limit of $60 \%$ is considered critical. It can be seen that this area has low fertility $(\mathrm{V}<50 \%)$, which means that the adopted soil management is not improving the availability of nutrients for the implanted crop. On the other hand, the spatial visualization of the distribution of $\mathrm{V} \%$ values may

Rev. Caatinga, Mossoró, v. 34, n. 1, p. 177 - 188, jan. - mar., 2021 
allow adjusting the fertilizing and liming practices.

\section{CONCLUSIONS}

The variation of nutrients in the area is possibly a reflection of the inadequate management of soil correction and fertilization, making the soil susceptible to degradation with the use of irrigation. The distribution maps of the area, identified the places with less and greater need for correction and fertilization, enabling the application of inputs with varying rates, aiming at homogenization of soil fertility.

\section{REFERENCES}

ALVARES, C. A. et al. Köppen's climate classification map for Brazil. Meteorologische Zeitschrift, Germany, 22: 711 - 728, 2013.

ALVES, P. F. S. et al. Soil chemical properties in banana crops fertigated with treated wastewater. Revista Caatinga, 32: 234-242, 2019.

BORGES, A. L.; SOUZA, L. S. Recomendação de adubação e calagem para bananeira. Cruz das Almas, BA: Embrapa Mandioca e Fruticultura, 2010. $5 \mathrm{p}$.

BOTTEGA, E. L. et al. Variabilidade espacial de atributos do solo em sistema de semeadura direta com rotação de culturas no cerrado brasileiro. Revista Ciência Agronômica, 44: 1-9, 2013.

CAMBARDELLA, C. A. et al. Field scale variability of soil properties in central Iowa soils. Soil Science Society of American Journal, 58: 1501-1511, 1994.

CARNEIRO, J. S. S. et al. Diagnóstico e manejo da variabilidade espacial da fertilidade do solo no cerrado do Piauí. Revista Ciência Agroambiental, 14: 11-21, 2016

CODEVASF. Companhia de Desenvolvimento dos Vales do São Francisco e do Parnaíba. Projetos Públicos de Irrigação. Disponível em: <http:// www.codevasf.gov.br/principal/perimetrosirrigados/ elencodeprojetos/nupeba-riacho-grande $>$. Acesso em: 05 jan. de 2020.

CÓRDOBA, M. et al. Subfield management class delineation using cluster analysis from spatial principal components of soil variables. Computers and Electronics in Agriculture, 97: 6-14, 2013.

DANTAS, J. D. N. et al. Qualidade do solo sob diferentes usos e manejos no perímetro irrigado de
Jaguaribe-Apodi, Brasil. Revista Brasileira de Engenharia Agrícola e Ambiental, 16: 1012-1022, 2012.

DONAGEMMA, G. K. et al. Manual de métodos de análise de solos. 2. ed. revisado, Rio de Janeiro, RJ: Embrapa Solos, 2011. 230 p.

FAO. Food and Agriculture Organization of the United Nations. Production, 2016. Disponível em: < http://www.fao.org/faostat/en/\#data/QC $>$. Acesso em: 15 jan. 2020 .

FERREIRA, L. L. N. et al. Spatial variability of available water and micro-sprinkler irrigation in cambisol. Revista Ceres, 63: 782-788, 2016.

GERUM, A. F. A. A. et al. Fruticultura Tropical: potenciais riscos e seus impactos. Cruz das Almas, BA: Embrapa Mandioca e Fruticultura, 2019. 28 p.

HAGHVERDI, A. et al. Perspectives on delineating management zones for variable rate irrigation. Computers and Electronics in Agriculture, 117: 154-167, 2015.

INMET. Ministério da Agricultura, Pecuária e Abastecimento. Instituto Nacional de Metereologia. Disponível em: <http:// www.inmet.gov.br/portal/index.php? $\mathrm{r}=$ home2/ index $>$. Acesso em: 15 jan. 2020.

LEITE, L. F. C. et al. Qualidade química do solo e dinâmica de carbono sob monocultivo e consórcio de macaúba e pastagem. Revista Brasileira de Engenharia Agrícola e Ambiental, 17: 1257-1263, 2013.

LIMA, F. V. et al. Variabilidade espacial de atributos físicos do solo em área de encosta sob processo de degradação. Revista Caatinga, 28: 53- 63, 2015.

LUNDGREN, W. J. C.; SILVA, J. A. A.; FERREIRA, R. L. C. A Precisão da Estimativa do Erro da Krigagem pela Validação Cruzada. Floresta e Ambiente, 24: 124-114, 2017.

MATIAS, S. S. R. et al. Variabilidade espacial dos atributos do solo em duas áreas de manejo convencional no Cerrado piauiense. Revista de Ciências Agrárias, 58: 217-227, 2015.

MATIAS, S. S. R. et al. Recomendação de calagem com base na variabilidade espacial de atributos químicos do solo no Cerrado brasileiro. Revista de Ciências Agrárias, 42: 896-907, 2019.

NEGREIROS NETO, J. V. et al. Variabilidade espacial de atributos físico-químicos de um Latossolo Vermelho-Amarelo distrófico em sistema 
plantio direto. Semina: Ciências Agrárias, 35: 193204, 2014.

PARIS, J. O. et al. Variability and spatial correlation of soil micronutrients and organic matter with macadamia nut production. Revista Brasileira de Engenharia Agrícola e Ambiental, 24: 31-36, 2020 .

PEREIRA, V. G. M. F. et al. Irrigação e fertirrigação no desenvolvimento de eucalipto. Ciência Florestal, 29: 1100-1114, 2019.

RIBEIRO, A. C.; GUIMARÃES, P. T. G.; ALVAREZ, V. V. H. Recomendações para o uso de corretivos e fertilizantes em minas gerais: $5^{\text {a }}$ aproximação. Viçosa, MG: Comissão de Fertilidade do Solo do Estado de Minas Gerais, 1999, 359 p.

ROBERTSON, G. P. GS+ geostatistics for the environmental sciences: GS+ user's guide. Plainwell: Gamma Design Software, 2008, 152 p.

SANTOS, H. G. et al. Sistema Brasileiro de Classificação de Solos. 5. ed. Rio de Janeiro, RJ: Embrapa Solos, 2018. 356 p.

SIQUEIRA, G. M. et al. Estacionariedade do conteúdo de água de um Espodossolo Humilúvico. Revista Brasileira de Engenharia Agrícola e Ambiental, 19: 439-448, 2015.

VIAN, A. L. et al. Variabilidade espacial da produtividade de milho irrigado e sua correlação com variáveis explicativas de planta. Ciência Rural, 46: 464-471, 2016.

WERNER, E. T. et al. Coeficiente de variação como medida da precisão em experimentos de cultura de tecidos de plantas. Plant Cell Culture \& Micropropagation, 8: 27-36, 2012.

YAO, R. J. et al. Determination of site-specific management zones using soil physico-chemical properties and crop yields in coastal reclaimed farmland. Geoderma, 232: 381-393, 2014. 